\title{
British and American Literature Course Reform Based on the TOPCARES-CDIO Engineering Education Mode
}

\author{
Qi Kang \\ Dalian Neusoft University of Information, No.8 Software Park Road, Dalian, Liaoning, China \\ kangqi@neusoft.edu.cn
}

Keywords: TOPCARES-CDIO, British and American Literature, Project Implementation.

\begin{abstract}
With social development and technological progress, more and more enterprises have come to realize the importance of cultivating employees' professional qualities, such as the innovative spirit and teamwork awareness. Under such circumstances, Dalian Neusoft University of Information has creatively put forward the concept of TOPCARES-CDIO and initiated systematic reforms in the curriculum construction, project implementation and teaching evaluation. Teachers of British and American literature have also integrated project teaching into the course construction. In this paper, the author makes an introduction of the innovative designs in the literature course in DNUI. Under the guidance of TOPCARES-CDIO concept, the innovative practice of flipped classroom teaching, the establishment of the resource sharing platform and the implementation of other projects get students greatly motivated in literary appreciation and ultimately improve their comprehensive qualities.
\end{abstract}

\section{Introduction}

The concept of CDIO engineering education has been introduced into China since the early $20^{\text {th }}$ century. It indicates that learners can effectively learn engineering design by conceiving, designing, implementing and operating a product or work [1]. This reform, which is operated on the project mode, has greatly facilitated students' project implementation and knowledge acquisition. Furthermore, the concept of TOPCARES-CDIO, conceived by DNUI, puts a focus on the realization of eight major indexes, namely technical knowledge and reasoning, open thinking and innovation, personal and professional skills, communication and teamwork, attitude and manner, responsibility, ethical values, and social contribution by application practice [2]. It has become the guideline for the university development. Under such circumstances, British and American literature course also carries out different reforms. At present, through designing and implementing projects in teaching, the course succeeds in cultivating students' comprehensive abilities.

\section{Current situation of British and American literature teaching}

British and American literature is a compulsory course for English majors. Traditionally, it is regarded as a theoretical course. Nowadays, with the development of modern teaching philosophy, many weaknesses have been identified, such as the broad curriculum setting, the shrinking teaching period, the overburdened teaching content and the single teaching and assessing criteria. Students are always burdened with a long literary history, while simultaneously are required to analyze and appreciate literary works. The teaching activities usually follow the pattern of background introduction, major works introduction and excerpt appreciation. In this kind of teacher-centered classroom, students are usually judged by whether they can understand and take in teachers' instructions. It is seen as a kind of passive learning experience for the students. With the subject development and renovation of teaching philosophy, the cultivation of students' comprehensive qualities, such as the critical thinking ability and cooperative spirit, has become a primary task. Universities now use network, computer and multimedia software to explore new teaching modes and promote individual learning experience. Therefore, the course of British and American literature is in 
an urgent need of reform. Under such circumstances, the literature teaching faculties in DNUI have made many attempts and these reforms have proven to be quite successful.

\section{Course introduction}

In DNUI, the British and American Literature course is opened to the English majors in the third academic year. Students are required to attend lectures for two academic hours each week and can get two academic credits when the course is over. It covers the British literature from the old and medieval period to the modern period and American literature from the colonial period to post-WWII period. Since the implementation of TOPCARES-CDIO educational reforms in DNUI, the literature course has emphasized both the cultivation of students' understanding and appreciation of literary works, and the enhancement of their comprehensive qualities. For example, it has helped students form good reading and critical thinking habits, enhance their understanding of western cultures, improve the intercultural communication and cultivate their sense of teamwork and cooperation. So far, there have appeared many dramatic changes since the innovative projects were implemented in literature course construction.

\section{Project implementation}

Teachers in DNUI have made many attempts in cultivating students' comprehensive qualities. In the following sections, the author gives an elaboration on the project implementation in the literature course in DNUI. It includes the flipped classroom project, the book talk project, the resource sharing project and the final paper writing project.

\subsection{Flipped classroom project}

In the traditional literature class, students are always instructed to follow the "preview-learn-review" procedure to acquire knowledge. Recently, with a focus on the cultivation of students' critical thinking and enhancement of their literary appreciation ability, teachers have introduced the flipped classroom mode into the course construction. Flipped classroom is an inversion of the traditional classroom mode, which advocates that students learning activity should be undertaken before class, while the classroom time is used for the consolidation of knowledge [3]. It reconstructs students' learning process, which allows them to learn in a much more personalized way, namely "learn before class, appreciate and discuss in class, and extend after class". Under the guidance of the new teaching mode, students are required to prepare the presentation before class and show it in class, which is about the social and literary background, author life experience and major works appreciation. Students are graded according to the content, language quality, performance and in-group communication during the process of project implementation. The quality of their presentation is guaranteed under teachers' supervision. The following table is one example of the flipped classroom teaching in literature class.

Table 1 Flipped classroom mode in British and American literature teaching.

\begin{tabular}{|c|c|c|c|}
\hline Ability & Content & Time & Learning Style \\
\hline $\begin{array}{l}\text { remember, } \\
\text { understand }\end{array}$ & $\begin{array}{l}\text { background information } \\
\text { author life experience and major works } \\
\text { excerpts }\end{array}$ & before class & self-study \\
\hline $\begin{array}{l}\text { apply, } \\
\text { analyze }\end{array}$ & $\begin{array}{l}\text { main character analysis } \\
\text { discussion on theme-related topics } \\
\text { literary style analysis }\end{array}$ & in class & $\begin{array}{c}\text { self-study } \\
\text { cooperative learning }\end{array}$ \\
\hline $\begin{array}{l}\text { evaluate } \\
\text { create }\end{array}$ & $\begin{array}{l}\text { evaluation of writing style, language features } \\
\text { literary works adaptation } \\
\text { paper writing } \\
\text { drama show }\end{array}$ & after class & $\begin{array}{c}\text { self-study } \\
\text { cooperative learning }\end{array}$ \\
\hline
\end{tabular}


Preview: This section enables students to enter the classroom with sufficient knowledge to improve the effectiveness of classroom activities. As is shown in the following table, they are encouraged to apply mind map tool to form clear pictures of the background information. The following table is the classification of elements concerning the concept of modernism in literature. Students first read the introduction of modernism in the reference books, then answer such theme-related questions as "What kind of influence does French philosopher Nietzsche, socialists Marx and Engels or Einstein have on literature?", "What do such terms as stream of consciousness or theatre of absurd mean?", or "Who are the representative novelists, poets or playwrights in the modern period? And what are their representative works?”. Students are suggested to do the research work by self-study before class.

Table 2 Background introduction of modernism.

\begin{tabular}{|c|c|c|}
\hline Influential Factors & Historical Period & Manifestations \\
\hline Nietzsche & & Theater of Absurd \\
\cline { 1 - 1 } Einstein & \multirow{3}{*}{ Modernism } & Existentialism \\
\cline { 1 - 1 } Marx \& Engels & & Scientific Socialism \\
\hline World War I\&II & & Stream of Consciousness \\
\hline
\end{tabular}

In-class activities: Each week, two or three students are invited to make presentations in class. They are graded according to the content, language quality, and performance of the presentation. Teacher designs some questions, which motivate students to hold in-group discussions. For example, when Thomas Hardy's Tess of D'urberville is introduced, teacher asks students to form groups to read the excerpt. Students will play the roles of Tess, Clare and narrator respectively. After reading the selected passage, they are given a few minutes to hold in-group discussions on such topics as "What is the character of Tess. To what extent is she a helpless victim?" or "Why is Angel unable to forgive Tess when she just bestowed the gift of forgiveness on him?". During this process, teacher walks around the classroom, listens to their opinions and gives necessary corrections. Later students are encouraged to share their opinions in class. This flipped classroom teaching mode improves students' language competence, strengthen their critical thinking ability and in all, promote their comprehensive qualities.

After-class extension: In-class time is definitely insufficient for students to have an overall understanding of the literary history. Teacher usually guides students to extend their reading after class and hold discussions when necessary. The discussions are always open-ended, which motivate students to improve their critical thinking ability. The extension activities can be demonstrated in many forms, such as drama show, adaptation of original works, or even poem reading activity.

\subsection{Book talk project}

Systematic reading is conducive to students' lifelong learning experience. In the western countries, the extensive reading activities have been regarded as important as the intensive reading course. Western educators have designed many reading activities to get students engaged in reading, for example, students are encouraged to find reading buddies, to design book talks, and to organize regular book fairs. In the literature course, they are constantly facing some open questions. In order to answer these questions, they need to read the book, talk about it, exchange ideas, and do some researches from different perspectives, such as writing styles and language features.

With the subject development, students taking the literature course in DNUI are required to design a book talk, the purpose of which is to get the reader or audience interested in the book, then inspire them to read it [4]. At the beginning, students are instructed to form groups and hold group discussions. They need several weeks to read the book and understand the plot development and major character analysis. Students are evaluated by their performance, book talk design, language quality and in-group communication. The project can be presented in different forms, for example, 
students can simply prepare a presentation, design a debating activity, or even shoot a documentary. Then they present the book talk to the audience. This project greatly motivates students' learning enthusiasm. The traditional teacher-centered classroom is transformed into a student-centered one. Teachers’ role has also been changed from being merely a lecturer to be a study facilitator.

\subsection{Establishment of information sharing platform}

In order to integrate students' self-study resources, teacher gives them instructions on how to select useful information, design micro-courses, establish WeChat platforms and organize information sharing activities. The micro-courses are conducted in a professional recording studio in DNUI. Since the beginning of this semester, four micro-courses have been updated onto the information sharing platform. Students also volunteer to join in some poetry reading activities, through which they master the rhythmic requirements of poetry reading and the use of audio processing tools. It enhances students' enthusiasm for literature study and professional qualities such as cooperative spirit and other professional responsibilities. The platform is conducive to both English majors and non-English majors, who have strong interests in literature study.

\subsection{End-of-term assessment}

The final assessment of literature course takes the form of paper writing in DNUI. Different from the traditional testing system, it focuses on the evaluation of students' critical thinking ability and academic writing skills. Students are encouraged to select one British or American writer as the research target. The paper may be about the character analysis, writing style appreciation or language feature analysis. Moreover, students are suggested to undertake some in-depth analyses and develop new perspectives to probe into the work. There is a need to do some research work at the beginning, which helps them understand the predecessors' research findings and form their new perspectives. During this process, they also learn the rules for academic writing, which is often quite challenging.

\section{Conclusion}

The TOPCARES-CDIO concept has brought reforms to the traditional teaching mode. Changes have also occurred in students' learning activities and performance evaluation. Definitely, modern education is still in need of systematic reforms and in-depth analyses. It is hoped that effective educational reforms will be functional to students in both enhancing their literature appreciation abilities and overall professional qualities.

\section{References}

[1] Qiong, Wu. On the present situation and countermeasures of English and American literature teaching [J]. Journal of Liaoning Normal College, (1):46, 2004.

[2] Tao, Wen. Explore and build an integrated TOPCARES-CDIO talent training mode, China Higher Education, 41-43, 2011.

[3] National English curriculum standards [Z], Department of Basic Education, Ministry of Education, 2007.

[4] Book Talk. April 2013. November 2018. <https://en.wikipedia.org/wiki/Book_talk> 